\title{
Increased Heparin Binding in Cystic Fibrosis: A Reflection of Altered Glycoprotein Biosynthesis?
}

\author{
RONALD D. PEARSON, AND A. HAROLD LUBIN \\ The Department of Pediatrics, Nutrition Division, Ohio State University and The Children's Hospital, Columbus,
} Ohio, USA

\section{Summary}

Some of the serum proteins which bind to heparin and contribute to the pH 5.57 "heparin binding capacity" of human serum are glycoproteins; those from cystic fibrosis serum were found to be $\mathbf{2 7 \%}$ higher in fucose (methylpentose) content, $27 \%$ lower in sialic acid content, and $31 \%$ lower in hexose content when compared to heparin-precipitated serum glycoproteins from normal control subjects. Hexosamine content of the heparin-precipitated serum glycoproteins was the same. Results of this preliminary investigation indicate that altered carbohydrate composition in serum glycoproteins may affect significantly their heparin binding capacity.

\section{Speculation}

The glycoprotein biosynthetic mechanism in cystic fibrosis is genetically altered and produces glycoproteins of abnormal carbohydrate composition which combine with normal, acidic, glycosaminoglycans to form insoluble, viscous complexes that hinder normal cellular and subcellular transport mechanisms and metabolic processes.

Cystic fibrosis, a generalized, autosomal recessive disease, in which there is usually a dysfunction of all or most of the exocrine glands of the body, occurs in approximately 1 in 2000 live births. Comprehensive reviews appear in the literature $(8,10,21,23,44$, $50,56)$ citing numerous efforts directed at discovering the basic defect(s) responsible for the disease.

In a recent report (49), we described a simple method which we used to demonstrate that individual sera from subjects with cystic fibrosis had a much higher capacity for the in vitro binding of heparin than did sera from a group of healthy controls. We suggested that the increased capacity of serum proteins to bind heparin would help to explain the subnormal rise in plasma activity of lipoprotein lipase (EC 3.1.1.3) observed by Slack $e t$ al. (54) in fibrocystic individuals after heparin was administered.

Previous research in cystic fibrosis involving in vitro techniques also suggested unique heparin-protein binding interactions; it was observed that heparin could negate or neutralize abnormalities which the reported "cystic fibrosis factor(s)" $(15,41,56)$ produced in sodium transport (42) and ciliary motility (28-30). Based upon previous theories that serum protein anomalies in cystic fibrosis $(1,61)$ probably result from differences in glycoproteins $(60)$, we decided to use our new in vitro technique to investigate if glycoprotein differences were implicated in heparin-protein binding interaction.

This paper describes a preliminary investigation the results of which suggest that glycoproteins of abnormal carbohydrate composition are responsible for our observations of an increased heparin-binding-capacity of serum protein(s) in cystic fibrosis (49).

\section{MATERIALS AND METHODS}

\section{SUBJECTS}

Ten patients, five males and five females, ages $13-36 \mathrm{yr}$ with a diagnosis of cystic fibrosis confirmed by clinical and laboratory evaluations were included in this study. The severity of their conditions was evaluated at 6 week intervals: three were classified as having mild disease progression, two as moderate, and five as severe. Twelve healthy individuals, six males and six females, ranging in age from $23-44 \mathrm{yr}$ served as controls. In this preliminary investigation, no attempt was made to match the age or sex of cystic fibrosis patients with controls, although a matching technique might eliminate potential biologic biases.

\section{SERUM}

Venous blood samples (nonfasting) were taken from the cystic fibrosis patients and from the normal controls after receipt of informed consent (65). The blood was allowed to clot at room teperature for $1 \mathrm{hr}$. After centrifugation, the serum was removed and stored in plastic tubes (Falcon \#2027, Falcon Plastics, Oxnard, $\mathrm{Ca}$.) at $4^{\circ} \mathrm{C}$ (for no longer than $48 \mathrm{hr}$ ) until the described analyses were performed.

\section{CHEMICALS}

All chemicals employed in the methodologies described were of reagent quality unless otherwise specified.

\section{HEPARIN-BOUND PROTEIN ISOLATION}

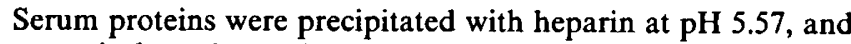
the protein-heparin precipitate redissolved as previously described (49).

\section{PROTEIN ANALYSIS}

Protein in serum (total protein) and in the precipitated heparinprotein pellet was determined by the method of Lowry et al. (39), using crystalline bovine albumin (Calbiochem, LaJolla, Ca.) as standard. In general, $10 \mu \mathrm{l}$ of a (1:20) dilution of serum in normal saline or $10 \mu \mathrm{l}$ of the $2.20 \mathrm{ml}$ redissolved "pellet solution" (49) contained sufficient protein for analysis when albumin standards ranged from $20-100 \mu \mathrm{g}$ of protein.

\section{HEPARIN QUANTITATION}

Heparin was determined indirectly by measuring the uronic acid content of the $2.20 \mathrm{ml}$ pellet solution. Uronic acid was determined by the carbazole method (24) as modified by Bitter and Muir (6) using D-Glucuronic Acid Lactone as standard (Sigma Chemical Co., St. Louis, MO). The heparin used throughout this study was determined to contain $30.0 \%$ uronic acid by weight. 


\section{CARBOHYDRATE ANALYSES}

Total protein-bound hexose, hexosamine, fucose (methylpentose), and sialic acid were determined in whole serum and in the heparin-precipitated proteins by methods described by Winzler (62). Total protein-bound hexose was determined by the method of Lustig and Langer (40) as employed by Weimer and Moshin (58) using Orcinol (Matheson, Coleman, and Bell, Norwood, Oh) with $\mathrm{D}(+)$-Mannose and $\mathrm{D}(+)$-Galactose (Sigma Chemical Co., St. Louis, MO as standards. In general, $100 \mu \mathrm{l}$ of whole serum or $200 \mu$ l of the pellet solution was sufficient for analysis with a 200 $\mu \mathrm{g}$ standard. Hexosamine was determined by the method of Rimimgton (52) using P-dimethyl-aminobenzaldehyde (Ehrlich's Reagent) (J. T. Baker Chemical Co., Phillipsburg, NJ) and D(+)Glucosamine Hydrochloride (Sigma Chemical Co., St. Louis, MO) as standard. In general, $100 \mu \mathrm{l}$ of whole serum or $200 \mu \mathrm{l}$ of the pellet solution was sufficient for analysis with a $50 \mu \mathrm{g}$ hexosamine standard.

Fucose was determined by the method of Dische and Shettles (27) using a Cysteine reagent (Cysteine Monohydrochloride (hydrate), Pfanstiehl Laboratories Inc., Waukegan, Ill) and the methylpentose $D(+)$-Fucose (Sigma Chemical Co., St. Louis, MO) as standard. In general, $100 \mu \mathrm{l}$ of whole serum or $200 \mu \mathrm{l}$ of the pellet solution was sufficient for analysis with a $20 \mu \mathrm{g}$ fucose standard.

Sialic acid was determined by the method of Ayala et al. (2) and Coburn et al. (12-14) as modified by Winzler (62) using Diphenylamine (Mallinkrodt Chemical Works, St. Louis, MO) with $\mathrm{N}$-Acetylneuraminic Acid (Calbiochem, LaJolla, CA) as standard. In general, $200 \mu \mathrm{l}$ of whole serum and $400 \mu \mathrm{l}$ of the pellet solution were sufficient for analysis using $20-200 \mu \mathrm{g}$ range of $\mathrm{N}$ acetylneuraminic acid (sialic acid) as standard.

Method Notes. (1) Initial alcoholic precipitation of proteins was eliminated for samples of the pellet solution, i.e., specifically for total protein-bound hexose, fucose, and hexosamine. (2) The heparin used throughout this study contained $6.79 \%$ by weight hexose and $13.16 \%$ by weight hexosamine. Consequently, the heparin contribution to values of total hexose and hexosamine in the heparin-protein precipitate was subtracted from the total to yield hexose and hexosamine bound only to the precipitated proteins. (3) Heparin gave no reactivity in the methods employed for fucose and sialic acid, nor did it interfere or react in the assay for protein. (4) While fucose is present as L-fucose in human glycoproteins, the methodology employed for fucose determination yields the same result when either the D-or L-isomers of fucose are used as standard (62).

Analysis of the Data. Statistical analyses for means, SD, linear regression analysis by method of least squares, and $t$ tests for the significance of the difference between two sample means were performed using an Olivetti Underwood Programma 101 desktop computer (Olivetti Underwood Corp., One Park Ave., New York, NY).

\section{RESULTS}

Table 1 presents data obtained from analyses for protein, heparin, and the protein:heparin ratio by weight as determined in the precipitate from $1 \mathrm{ml}$ of serum for cystic fibrosis patients and from control subjects. More protein and proportionately more heparin (Table 1) are precipitated from $1 \mathrm{ml}$ of serum from cystic fibrosis individuals than from control subjects. The weight ratio by which protein and heparin combine to precipitate from the buffered solution (Table 1), is significantly different between the two groups. An average $25 \%$ less protein combines per unit weight of heparin to precipitate from solution for the cystic fibrosis group than for the controls.

Results of analyses of the total serum proteins for some individual carbohydrate constituents of serum glycoproteins, specifically, hexose, hexosamine, fucose, and sialic acid are presented in Table 2. Only the carbohydrate moiety hexosamine is increased significantly in the cystic fibrosis group relative to the control group, and protein-bound hexosamine is known to be increased in chronic pulmonary and liver disease $(55,63)$.

Results for the carbohydrate composition of the precipitated serum proteins and their relation to the carbohydrate composition of the total serum proteins are presented in Tables 3, 4, and 5. Only hexosamine differences in the precipitated proteins were expected because only hexosamine in the total serum proteins was observed to be increased in the cystic fibrosis subjects (Table 2). However, while the total serum protein-bound hexosamine is increased for the cystic fibrosis group (Table 3), the quantity of hexosamine precipitated (Table 3), and the hexosamine composition of the precipitated proteins as a weight per cent (Table 3 ) is decreased compared to normal controls.

No differences in hexose, fucose, or sialic acid composition of

Table 1. Heparin protein precipitate data for 10 Cystic Fibrosis subjects and 12 normal controls

\begin{tabular}{|c|c|c|c|c|c|}
\hline \multirow[b]{2}{*}{ Constituent } & \multicolumn{2}{|c|}{ Cystic Fibrosis } & \multicolumn{2}{|c|}{ Normal controls } & \multirow[b]{2}{*}{ Statistical significance } \\
\hline & Mean \pm 1 SD & $\mathbf{n}$ & Mean $\pm 1 \mathrm{SD}$ & $\mathbf{n}$ & \\
\hline Protein precipitated by heparin from one milliliter serum (mg) & $17.69 \pm 8.875$ & 10 & $13.82 \pm 2.287$ & 12 & $\mathrm{NS}^{1}$ \\
\hline Heparin precipitated with protein from one milliliter serum $(\mathrm{mg})$ & $1.206 \pm 0.723$ & 10 & $0.593 \pm 0.086$ & 12 & $P<0.025$ \\
\hline Protein: heparin combining ratio by weight in the precipitate & $15.74 \pm 2.64$ & 10 & $23.39 \pm 3.12$ & 12 & $P<0.001$ \\
\hline
\end{tabular}

' NS = Not statistically significant in relation to controls.

Table 2. Results of analyses of the total serum proteins of Cystic Fibrosis and normal control subjects for carbohydrate constituents usually present in serum glycoproteins

\begin{tabular}{|c|c|c|c|c|c|}
\hline \multirow[b]{2}{*}{ Constituent (mg/100 ml serum) } & \multicolumn{2}{|c|}{ Cystic Fibrosis } & \multicolumn{2}{|c|}{ Normal controls } & \multirow[b]{2}{*}{ Statistical significance } \\
\hline & Mean $\pm 1 \mathrm{SD}$ & $\mathbf{n}$ & Mean $\pm 1 \mathrm{SD}$ & $\mathrm{n}$ & \\
\hline Total protein-bound hexose (as galactose; mannose, $1: 1$ ) & $82.53 \pm 23.68$ & 10 & $85.53 \pm 7.00$ & 11 & $\mathbf{N S}^{\prime}$ \\
\hline Total protein-bound hexosamine (as glucosamine) & $116.93 \pm 26.14$ & 10 & $92.76 \pm 12.99$ & 11 & $P<0.025$ \\
\hline Total protein-bound fucose (as D-fucose) & $7.21 \pm 3.56$ & 10 & $6.67 \pm 1.78$ & 12 & NS $^{1}$ \\
\hline Total protein-bound sialic acid (as $\mathrm{N}$-acetylneuraminic acid) & $79.31 \pm 17.33$ & 10 & $85.59 \pm 14.87$ & 12 & $\mathrm{NS}^{1}$ \\
\hline
\end{tabular}

\footnotetext{
${ }^{1}$ NS $=$ Not statistically significant in relation to controls.
} 
Table 3. Hexosamine content of the total and heparin-precipitated serum proteins of the Cystic Fibrosis and normal control subjects

\begin{tabular}{|c|c|c|c|c|c|}
\hline \multirow[b]{2}{*}{ Constituent } & \multicolumn{2}{|c|}{ Cystic Fibrosis } & \multicolumn{2}{|c|}{ Normal Control } & \multirow[b]{2}{*}{ Statistical significance } \\
\hline & Mean $\pm 1 \mathrm{SD}$ & $\mathrm{n}$ & Mean $\pm 1 \mathrm{SD}$ & $\mathrm{n}$ & \\
\hline $\begin{array}{l}\text { Protein-bound hexosamine in total serum proteins }(\mathrm{mg} / 100 \mathrm{ml} \\
\text { serum) (as glucosamine) }\end{array}$ & $116.93 \pm 26.14$ & 10 & $92.76 \pm 12.99$ & 11 & $P<0.025$ \\
\hline $\begin{array}{l}\text { Protein-bound hexosamine in protein precipitated from } 1 \mathrm{ml} \\
\text { serum }(\mu \mathrm{g} / \mathrm{ml} \text { serum })\end{array}$ & $165.44 \pm 53.07$ & 10 & $193.32 \pm 114.69$ & 12 & $\mathrm{NS}^{1}$ \\
\hline $\begin{array}{l}\text { Ratio hexosamine/protein in the precipitate as a weight percent } \\
(\mu \mathrm{g} \text { hexosamine } / \mu \mathrm{g} \text { protein } \times 100)\end{array}$ & $1.056 \pm 0.488$ & 10 & $1.394 \pm 0.338$ & 12 & $\mathrm{NS}^{1}$ \\
\hline
\end{tabular}

${ }^{1} \mathrm{NS}=$ Not statistically significant in relation to controls.

Table 4. Comparison of the fucose and sialic acid content of the serum proteins of the Cystic Fibrosis and control subjects

\begin{tabular}{|c|c|c|c|c|c|}
\hline \multirow[b]{2}{*}{ Constituent } & \multicolumn{2}{|c|}{ Cystic Fibrosis } & \multicolumn{2}{|c|}{ Normal control } & \multirow[b]{2}{*}{ Statistical significance } \\
\hline & Mean \pm 1 SD & $\mathrm{n}$ & Mean \pm 1 SD & $\mathbf{n}$ & \\
\hline Protein-bound fucose precipitated $(\mu \mathrm{g} / \mathrm{ml}$ serum) & $23.41 \pm 11.04$ & 10 & $13.99 \pm 4.06$ & 11 & $P<0.03$ \\
\hline $\begin{array}{l}\text { Ratio fucose/protein in the precipitate as a weight percent }(\mu \mathrm{g} \\
\text { fucose } / \mu \mathrm{g} \text { protein } \times 100)\end{array}$ & $0.133 \pm 0.013$ & 10 & $0.105 \pm 0.024$ & 11 & $P<0.005$ \\
\hline Protein-bound sialic acid precipitated $(\mu \mathrm{g} / \mathrm{ml}$ serum) & $79.20 \pm 19.79$ & 10 & $93.89 \pm 28.91$ & 12 & $\mathrm{NS}^{1}$ \\
\hline $\begin{array}{l}\text { Ratio sialic acid/protein in the precipitate as a weight percent } \\
(\mu \mathrm{g} \text { sialic acid } / \mu \mathrm{g} \text { protein } \times 100)\end{array}$ & $0.509 \pm 0.150$ & 10 & $0.698 \pm 0.105$ & 10 & $P<0.01$ \\
\hline $\begin{array}{l}\text { Ratio fucose/sialic acid in the precipitated serum proteins }(\mu \mathrm{g} / \\
\mu \mathrm{g})\end{array}$ & $0.288 \pm 0.092$ & 10 & $0.146 \pm 0.043$ & 11 & $P<0.001$ \\
\hline Ratio fucose/sialic acid in total serum proteins $(\mathrm{mg} / \mathrm{mg}$ ) & $0.087 \pm 0.030$ & 10 & $0.079 \pm 0.020$ & 12 & NS $^{1}$ \\
\hline
\end{tabular}

'NS = Not statistically significant in relation to controls.

Table 5. Comparison of the fucose and hexose content of serum proteins of the Cystic Fibrosis and normal control subjects

\begin{tabular}{|c|c|c|c|c|c|}
\hline Constituent & \multicolumn{2}{|c|}{ Cystic Fibrosis } & \multicolumn{2}{|c|}{ Normal control } & Statistical significance \\
\hline Protein bound hexose precipitated $\mu \mathrm{g} / \mathrm{ml}$ serum & $208 \pm 74.39$ & 10 & $260.0 \pm 47.29$ & 11 & $\mathbf{N S}^{1}$ \\
\hline $\begin{array}{l}\text { Ratio hexose/protein in the precipitate as a weight percent }(\mu \mathrm{g} \\
\text { hexose } / \mu \mathrm{g} \text { protein } \times 100)\end{array}$ & $1.308 \pm 0.475$ & 10 & $1.907 \pm 0.193$ & 11 & $P<0.005$ \\
\hline Ratio fucose/hexose in the precipitated proteins $(\mu \mathrm{g} / \mu \mathrm{g})$ & $0.116 \pm 0.047$ & 10 & $0.054 \pm 0.016$ & 11 & $P<0.001$ \\
\hline
\end{tabular}

\footnotetext{
' NS = Not statisitcally significant in relation to controls.
}

the precipitated proteins were expected between the cystic fibrosis and control groups as judged from the total serum protein carbohydrate values (Table 2). However, comparisons of the fucose and sialic acid composition (Table 4) and of the fucose and hexose composition (Table 5) of the precipitated proteins showed highly significant differences. The quantity of fucose precipitated (Table 4 ), and the fucose composition of the precipitated proteins as weight percent (Table 4) were significantly increased for the cystic fibrosis group. The quantity of the sialic acid precipitated (Table 4) and the sialic acid composition of the precipitated proteins (Table 4) generally was decreased for the cystic fibrosis group, although not significantly. The ratio of fucose to hexose found in the total serum proteins of the two groups was compared (Table 5), no significant difference was found, but comparisons of the fucose composition (Table 4) and the hexose composition (Table 5) of the precipitated proteins showed highly significant differences between the two groups. Cystic fibrosis precipitated proteins were increased in fucose content and decreased in hexose content when compared to controls. Consequently, the ratio of the fucose/ hexose composition of the precipitated proteins (Table 5) is greatly increased for the cystic fibrosis group and is even more highly significant.

\section{DISCUSSION}

Previous cystic fibrosis research reports indicate that glycoprotein biosynthesis is generally altered in most, if not all, cell types which synthesize glycoproteins, whether for secretory purposes, or for normal cellular growth, maintenance, and repair. In particular, the incorporation of the methylpentose sugar, fucose, seems aberrant.

Altered fucose metabolism in cystic fibrosis was first suggested by Dische et al. (25) who showed that, in a certain ethanol benzene insoluble fraction of glycoproteins from duodenal mucus secre- 
tions from patients with cystic fibrosis, the ratio of fucose to sialic acid and to total protein was higher than in the other fractions from the same duodenal mucus sample. Dische et al. (25) proposed that the abnormal shift in sugars (fucose increase, sialic acid decrease) might lead to an increase in molecular size and, thus, to decreased solubility and increased viscosity. This same glycoprotein fraction was previously shown to be resistant to the digestion action of trypsin (21). This finding may also have implications for the works of Wilson and Fudenberg (60), who demonstrated a deficient proteolytic cleavage of $\alpha_{2}$-macroglobulin in cystic fibrosis plasma, and for Shapira et al. (53) who demonstrated an abnormal complex between trypsin-like proteases and cystic fibrosis $\alpha_{2}$ macroglobulin, a serum glycoprotein known to contain fucose (55).

There is evidence that salivary glands produce, in addition to their specific secretions, glycoproteins similar to those in mucus (26). Recently, Ghua et al. (32) have shown that there is a greater incorporation of fucose by fucosyl transferase into acceptor glycoproteins prepared from cystic fibrosis saliva than those prepared from normal saliva. Additional preliminary isoelectric focusing studies of the acceptor glycoproteins suggest an altered apoglycoprotein (peptide) structure, with, perhaps, increased binding-sites for fucose terminated oligo- or polysaccharides. These results, although preliminary, suggest a genetic defect in the control of production of the peptide portion of the glycoprotein molecule, creating an abnormal proportion of fucose-terminated oligo- or polysaccharides in the presence of a normal activity level of fucosyl transferase (32).

Glycoprotein biosynthesis in cultured fibroblasts from skin of cystic fibrosis patients has also been extensively studied $(21,23)$. While some of the investigations have not produced consistent, identifiable differences in glycoprotein metabolism by fibroblasts in general $(3,11)$, some investigators have demonstrated differences which may directly affect glycoprotein biosynthesis or, be the result of an abnormality in the glycoprotein biosynthetic mechanism. Novak and Abell (47) have shown that fibroblasts from skin of cystic fibrosis patients secrete greater amounts of low molecular weight, fucose-containing glycopeptides as components of soluble glycoproteins. They found that normal fibroblasts preferentially incorporate fucose into higher molecular weight glycopeptides. This result, that there is an increased incorporation of fucose into low molecular weight glycopeptides, is consistent with the earlier work of Dische et al. (25), the finding of an increased ratio of fucose to total protein (total peptides).

Other evidence from fibroblast research, recently published by Rao et al. (51), supports an abnormality in the glycoprotein biosynthetic mechanism. They showed that the activity of an enzyme which incorporates galactose into the carbohydrate chains of glycoproteins is increased, specifically UDP-galactose:glycoprotein galactosyl transferase. What exact relationship this finding has to the incorporation of fucose into fibroblast-secreted glycoproteins remains to be investigated. However, because fucose occurs in glycoproteins as a terminal sugar of carbohydrate side chains, the production of an increased number of shorter chain (lower molecular weight) carbohydrate side chains might allow for increased fucose incorporation. This finding, then, would be consistent with the work of Novak and Abell (47).

Additional evidence to support an abnormality in the glycoprotein biosynthetic mechanism at the subcellular level in cystic fibrosis was obtained from studies on lung tissue. Louisot and Leurat (38) demonstrated a hyperactivity of several glycosyl transferases at the microsomic levels in lung tissue, particularly in fucosyl transferase. If fucosyl transferase were hyperactive in all cell types producing glycoproteins in cystic fibrosis, it would, then, account for the increased incorporation of fucose, especially if the peptide portions of cystic fibrosis glycoproteins are biosynthesized with increased numbers of acceptor sites for fucose-terminated carbohydrate side chains (32) and/or increased amounts of fucoseterminated carbohydrate side chains are biosynthesized.

Previously, serum glycoprotein abnormalities have only been suggested by the work of Wilson et al. (61) on $\alpha_{2}$-macroglobulin, a macroglobulin whose carbohydrate composition and amino acid sequences are known (55). Using isoelectric focusing techniques, Wilson and Fudenberg (60) demonstrated that $\alpha_{2}$-macroglobulin, a fucose-containing glycoprotein, from cystic fibrosis patient serum was not proteolytically cleaved to the same degree by enzymes which would break down $\alpha_{2}$-macroglobulin from normal control serum. This observation is very interesting considering the observation of Dische et al. (21) that the mucous glycoprotein fraction of increased fucose content was also resistent to proteolytic cleavage by trypsin. Wilson and Fudenberg (60) did not determine the fucose content of the $\alpha_{2}$-macroglobulin, however, so attempts to correlate reduced proteolytic degradation with increased fucose content in $\alpha_{2}$-macroglobulin are premature.

Our investigation of serum glycoproteins in cystic fibrosis also supports the concept of generally altered glycoprotein biosynthesis in cystic fibrosis. Our results concerning the carbohydrate composition of proteins in sera from cystic fibrosis subjects precipitated by heparin in an in vitro system indicate that these proteins are, at least in part, glycoproteins which are significantly different in cystic fibrosis subjects in their hexose, fucose, and sialic acid content and in overall proportions of those carbohydrates which are bound to the protein peptide moiety (Tables 3-5). In general, precipitated cystic fibrosis glycoproteins, when compared to the precipitated normal glycoproteins, are $27 \%$ higher in fucose content, $27 \%$ lower in sialic acid content, and are $31 \%$ lower in hexose content (refer to Tables 4 and 5). The exact identity of the glycoproteins which are precipitated remains to be determined, but the collective increase in the fucose content of the precipitated glycoproteins and the significant increase in the ratio of fucose to protein and to hexose and sialic acid supports the hypothesis that at least one or more serum glycoproteins is the product of a biosynthetic mechanism incorporating increasing amounts of fucose into glycoprotein.

While salivary, mucus, fibroblast, and serum glycoproteins are produced by different cell types and have distinctive physicochemical compositions, the biochemical synthetic processes involved in their production are believed to occur in similar subcellular microsomal sites with similar enzymatic systems $(32,55)$. A recently proposed pathway for plasma glycoprotein biosynthesis (46) provides evidence that glycoproteins are synthesized sequentially at three different subcellular sites: 1) the membrane-bound ribosomes, 2) the lumen of the endoplasmic reticulum, and 3) at the golgi apparatus. The biosynthetic reactions are carried out by enzymes strongly bound to the membranes. The final structure of the glycoprotein molecule is determined by specific glycosyltransferase enzymes which add specific carbohydrates (e.g., hexose, fucose, hexosamines, sialic acids) to the glycoprotein in amounts regulated by relative enzyme activity and specific carbohydrate nucleotide substrate availability. The completed glycoproteins are packed into secretory vesicles in the golgi apparatus and transferred to the blood after fusion of the vesicles with the cell membrane $(5,46,57)$. This process is thought to be similar in other cell types.

The biosynthesis of glycoproteins is under genetic regulation of two types. Direct genetic regulation occurs during the assembly of the glycoprotein peptide moiety; indirect genetic regulation occurs during assembly and attachment of the carbohydrate chain moieties to the peptide portion of the glycoprotein molecule $(46,55)$. Interactions of variable complexity between single defective alleles or among multiple defective alleles which code for the assembly of the peptide portion of glycoproteins (direct regulation) and of the enzymes involved in assembly and attachment of the carbohydrate chain moieties to the glycoprotein peptide structure(s) (indirect regulation) may give rise to glycoproteins of abnormal composition, particularly increased in fucose content.

Our results demonstrate that certain serum proteins from cystic fibrosis serum, at least some of which are glycoproteins of abnormal composition, have a higher than normal capacity to bind and combine with heparin, an acidic glycosaminoglycan (Fig. 1). The increased fucose content (Fig. 2) and lowered sialic acid and hexose content (Fig. 3) in these not-yet-identified proteins may 

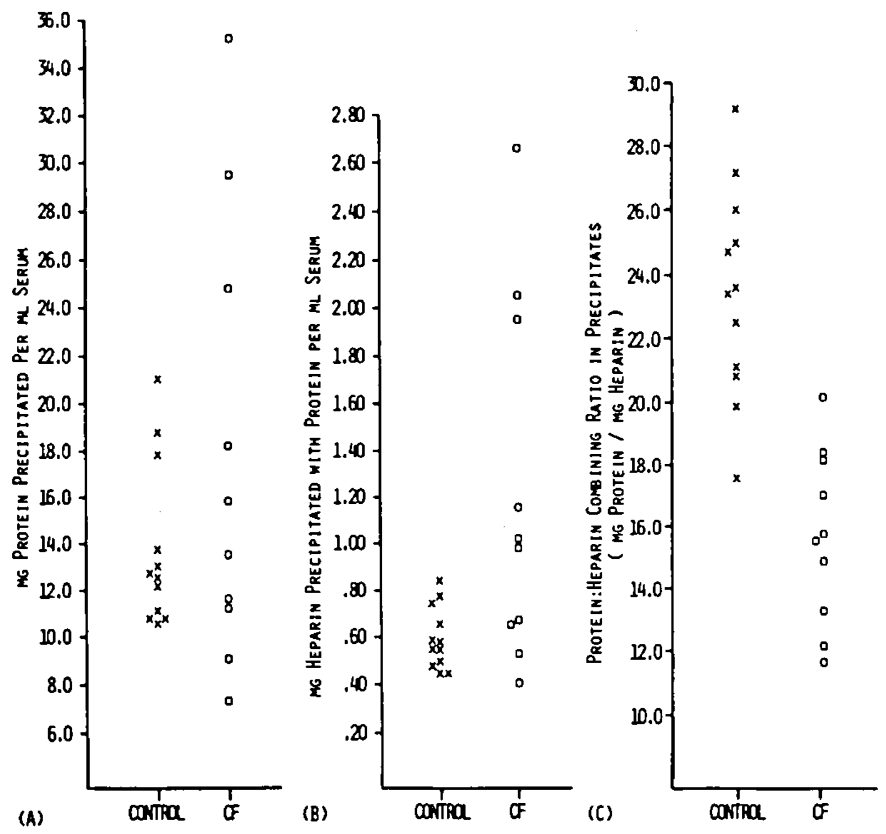

Fig. 1. Scatter diagrams showing discrete value distributions for normal controls and cystic fibrosis patients for: $(A)$ milligrams of protein precipitated by heparin from serum diluted $1 / 30$ in $\mathrm{pH} 5.57$ buffer; $(B)$ milligrams of heparin complexed with protein in the precipitates; and, $(C)$ the weight ratio at which serum proteins combined with heparin at $\mathrm{pH} 5.57$ to precipitate from solution.
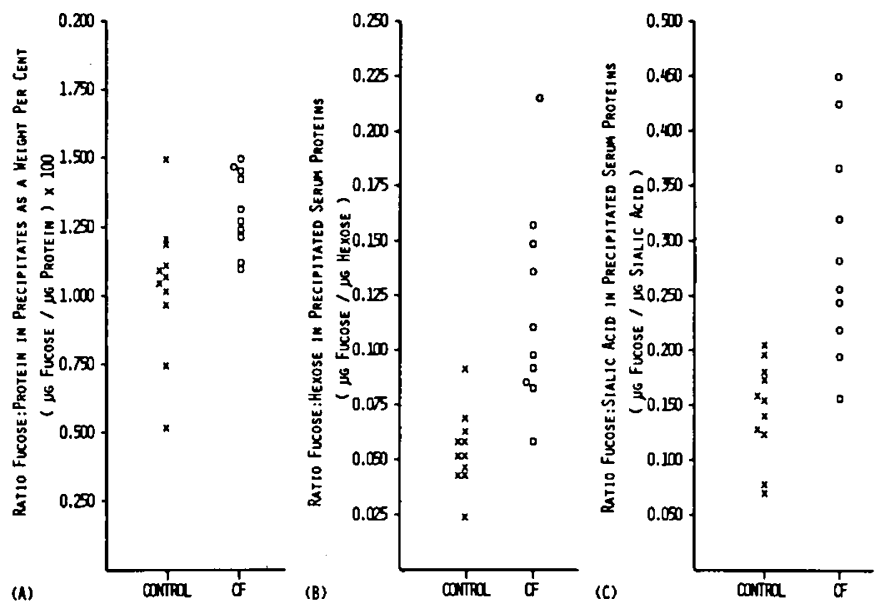

Fig. 2. Scatter diagrams showing discrete value distributions which reveal differences in cystic fibrosis serum proteins precipitated by heparin at $\mathrm{pH} 5.57(A)$ Increased fucose content of precipitated cystic fibrosis serum proteins. $(B)$ Increased proportion of fucose content over hexose content (as galactose:mannose, 1:1) of precipitated cystic fibrosis serum proteins. $(C)$ Increased proportion of fucose content over sialic acid content (as $\mathrm{N}$-acetyl-neuraminic acid) of precipitated cystic fibrosis serum proteins.

have altered the protein structure (secondary, tertiary, and/or quaternary), so that heparin is bound in greater quantities than for the precipitated normal proteins in an in vitro system (Table 1). It is of interest to note that Dogget and Harrison (28-30) demonstrated that heparin negated the ciliostatic effect of cystic fibrosis serum factors in in vitro and in in vivo experiments. These studies also suggested an unusual binding of heparin by factors in cystic fibrosis serum.

If glycoprotein biosynthesis is generally defective to varying degrees in different cell types in cystic fibrosis, and glycoproteins of increased fucose content are produced in amounts proportional to the degree of severity of the genetic defect, then it is possible that abnormal complexes of acidic glycosaminoglycans with gly-

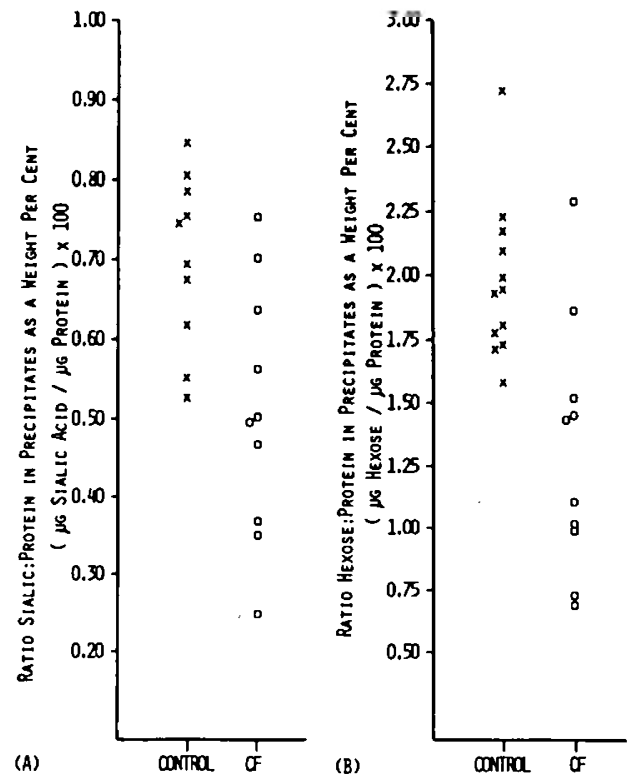

Fig. 3. Scatter diagrams showing discrete value distributions which reveal differences in cystic fibrosis serum proteins precipitated by heparin at $\mathrm{pH}$ 5.57. $(A)$ Decreased sialic acid content (as N-actyl-neuraminic acid) of precipitated cystic fibrosis serum proteins. $(B)$ Decreased hexose content (as galactose:mannose, 1:1) of precipitated cystic fibrosis serum proteins.

coproteins of increased fucose content and lowered sialic acid and hexose content would be formed within cells which are also active producers of glycosaminoglycans. It is interesting to note that the biosynthesis of acidic glycosaminoglycans such as heparin, the chondroitin sulfates, and hyaluronic acid involves the golgi apparatus $(31,63)$, which is used also for the completion of glycoproteins (46).

Skin fibroblasts, active producers of fucose-containing glycoproteins and acidic glycosaminoglycans, have been used in numerous investigations in cystic fibrosis $(4,19,20,37,43,45,59)$. Some of these investigators have previously observed an increased, but variable, metachromatic inclusion-body content in some cultured cystic fibrosis cell lines $(4,7,19,37,45)$. Acidic glycosaminoglycans among other substances are known to cause metachromasia with certain dyes $(18,48,64)$. Based on our recent observation of an increased binding of an acidic glycosaminoglycan (heparin) to the glycoproteins of increased fucose content, and the known commonality of the golgi apparatus for biosynthetic completion of both glycoproteins and glycosaminoglycans $(46,57)$, we speculate that during the biosynthetic completion of abnormal glycoproteins of increased fucose content and of normal acidic glycosaminoglycans at the golgi apparatus, a complex is formed which is disproportionately high in acidic glycosaminoglycan content over protein content because of the increased binding affinity of the abnormal fucose-containing glycoproteins. This glycoprotein-glycosaminoglycan complex would be difficult to remove by normal cellular secretory mechanisms. Small intracellular inclusion bodies (possibly lysosomes or golgi apparatus secretory fragments) rich in this complex would accumulate because the enzymatic intracellular degradation of the glycoproteins in the complex would be sterically hindered (9), and cells are known to store within themselves inclusion bodies containing materials which are difficult to remove $(33,34)$.

In cystic fibrosis patients, cells of organs most severely affected by the disease (lungs, pancreas, liver, and intestine) are active producers of glycoproteins (55). In some organs, apparently abnormal secretions precipitate or coagulate to form eosinophilic concretions in the ducts and obstruct outflow of secretions leading to dilation of the secreting gland itself (pancreas, submaxillary glands, intrahepatic bile ductules, and prostate). Most of the pathologic changes and clinical symptoms in cystic fibrosis (pancreatic fibrosis and achylia, bronchial obstruction, and hepatic 
cirrhosis) are thought to be secondary to this kind of obstruction (21). Because of the complex phenotype expressions of cystic fibrosis (16) generally observed as a heterogeneity of clinical presentations (especially characterized by individuals with pulmonary difficulties, others mainly with gastrointestinal problems, those with multisystemic involvement, and those few with little difficulty other than sweat electrolyte abnormalities), the resultant clinical manifestations of cystic fibrosis (17) could be related genetically to defects in the glycoprotein biosynthetic mechanisms.

We believe that research in fucose incorporation into glycoproteins in cystic fibrosis should be intensified in light of our current findings and the previous findings of other investigators who have studied glycoproteins in cystic fibrosis. Perhaps the finding of an increased heparin affinity by glycoproteins of increased fucose content will prove to be a useful research tool for preliminary isolations of glycoproteins of increased fucose content, which can then be purified by other techniques and studied for their effects on normal cellular secretory functions and plasma membrane functions (ion transport mechanisms) which are known to be abnormal in cystic fibrosis $(21,23,35,36,41)$. We plan to pursue additional studies with the serum glycoprotein fraction of increased fucose content and increased heparin binding capacity to identify and fully characterize the total number and different kinds of proteins precipitated by heparin at $\mathrm{pH} 5.57$ in our in vitro system, especially with regard to the exact amino acid and carbohydrate composition and their sequences, the physical structure of those proteins, and any possible immunologic differences that may exist between the cystic fibrosis and normal heparin-precipitated poteins.

\section{REFERENCES AND NOTES}

1. Atland, K., Schmidt, S. R., Kaiser, G., and Knoche, W.: Demonstration of a factor in the serum of homozygotes and heterozygotes for cystic fibrosis by a non biological technique. Humangenetik, 28: 207 (1975).

2. Ayala, W.,Moore, L. V., and Hess, E. L.: J. Clin. Invest., 30: 781 (1951).

3. Baig, M. M., Cetorelli, J. J., and Roberts, R. M.: Plasma membrane components of skin fibroblasts from normal individuals and patients with cystic fibrosis. $J$. Pediatr. 86(i): 72 (1975).

4. Bartman, H., Weismann, U., and Blanc, W. A.: Ultrastructure of cultivated fibroblasts in cystic fibrosis of the pancreas. J. Pediatr. 76: 430 (1970).

5. Bennett, G., Leblond, C. P., and Haddad, A.: Migration of glycoprotein from the golgi apparatus to the surface of various cell types as shown by radioautography after labeled fucose injection into rats. J. Cell Biol., 60: 258 (1974).

6. Bitter, T., and Muir, H. M.: A modified uronic acid carbazole reaction. Anal. Biochem., 4: 330 (1962).

7. Boat, T. F., Kleinerman, J. I., Carlson, D. M., Maloney, W. H., and Mathews, L. W: Human respiratory tract secretions. 1. Mucous glycoprotein secreted by cultured nasal polyp epithelium from subjects with allergic rhinitis and with cystic fibrosis. Am. Rev. Respir. Dis., 110: 428 (1974).

8. Bowman, B. H.: Introduction: progress in research toward identifying the basic defect in cystic fibrosis. Tex. Rep. Biol. Med., 31: 611 (1973).

9. Butterworth, J., Scott, F., McCrae, W. M., and Bain, A. D.: Lysosomal enzymes of cultured fibroblasts of cystic fibrosis patients. Clin. Chim. Acta, 40: 139 (1972).

10. Changus, J. E., and Pitot, H. C.: Cystic fibrosis. A dilemma in the metabolic pathogenesis of genetic disease. Arch. Pathol. Lab. Med. 100: 7 (1976).

11. Changus, J. E., Quissell, D. O., Sukup, M. R., and Pitot, H. C.: Studies on the synthesis of plasma membrane proteins of fibroblasts from patients with cystic fibrosis. Amer. J. Pathol., 80(2): 317 (1975)

12. Coburn, A. F., and Haninger, J.: Trans. Assoc. Am. Physicians. 66: 308, (1953)

13. Coburn, A. F., and Haninger, J.: J. Exp. Med., 99: 1 (1954).

14. Coburn, A. F., Moore, L. U., and Haninger, J.: Arch. Intern. Med., 92: 185 (1953).

15. Conod, E. J., Conover, J. H., and Hirschhorn, K.: Demonstration of human leukocyte degranulation induced by sera from homozygotes and heterozygotes for cystic fibrosis. Pediatr. Res., 9: 724 (1975).

16. Conneally, P. M., Merritt, A. D., and Pao-Lu-Yu. Cystic fibrosis: population genetics. Tex. Rep. Biol. Med., 31: 640 (1973).

17. Cunningham, D. G.: Clinical variations of cystic fibrosis. Ill. Med., J. 145: 493 (1974).

18. Curran, R. C.: The histological demonstration of connective tissue mucopolysaccharides. Biochem. Soc. Symp., 20: 24 (1961).

19. Danes, B. S.: Association of cystic fibrosis factor to metachromasia of the cultured cystic fibrosis fibroblast. Lancet, 2: 765 (1973).

20. Danes, B. S., and Bearn, A. G.: Cystic fibrosis of the pancreas. A study in cell culture. J. Exp. Med., 127: 775 (1969).

21. DiSant'Agnese, P. A., and Davis, P. B., Research in cystic fibrosis. N. Engl. J. Med., 295: 481 (1976).
22. DiSant'Agnese, P. A., Dische, Z., and Danilezenko, A.: Physicochemical differences of mucoproteins in duodenal fluid of patients with cystic fibrosis of the pancreas and controls. Pediatrics, 19: 252 (1957).

23. DiSant'Agenese, P. A., and Talamo, R. C.: Pathogenesis and pathophysiology of cystic fibrosis of the pancreas. N. Engl. J. Med., 277: 1287 (1967).

24. Dische, Z.: A new specific color reaction of hexuronic acids. J. Biol. Chem., 167: 189 (1947).

25. Dische, Z., DiSant'Agnese, P. A., Pallavicini, C., and Youlos, J.: Composition of mucoprotein fractions from duodenal fluid of patients with cystic fibrosis and from controls. Pediatrics, 24: 74 (1959).

26. Dische, Z., Pallavicini, L. J., and Chien, S.: Ann. N. Y. Acad. Sci., 93: 526 (1962) 27. Dische, Z., and Shettles, L. B.: J. Biol. Chem., I75: 595 (1948).

28. Dogget, R. G., and Harrison, G. M.: Cystic fibrosis: in vitro reversal of the ciliostatic character of serum and salivary secretions by heparin. Nature (New Biol.), 243: 251 (1973).

29. Dogget , R. G., and Harrison, G. M.: Cystic fibrosis: reversal of ciliary inhibition in serum and saliva by heparin. Tex. Rep. Biol. Med., 31: 685 (1973).

30. Dogget, R. G., Harrison, G. M., and Patrick, T. A.: Cystic fibrosis: in vivo reversal of the ciliostatic character of serum and parotid secretion by heparin. Nature (New Biol.) 243: 250 (1973).

31. Ehrlich, J., and Stivala, S. S.: The chemistry and pharmacology of heparin. J. Pharm. Sci., 62: 514 (1973).

32. Ghua, A. K., Kutty, K. M., Chandra, R. K., and Way, R. C.: A study of the salivary glycoprotein in cystic fibrosis patients and controls: fucose incorporation and protein pattern. Clin Biochem., 10(4): 153 (1977).

33. Goldberg, A. L., and Dice, J. F.: Intracellular protein degradation in mammalian and bacterial cells (part 1). Annu. Rev. Biochem. 45: 835 (1974).

34. Goldberg, A. L., and Dice, J. F.: Intracellular protein degradation in mammalian and bacterial cells (part 2). Annu. Rev. Biochem., 45: 747 (1976).

35. Gibson, L. E., Matthews, W. J., Minihan, P. T., and Patti, J. A.: Relating mucous, calcium and sweat in a new concept of cystic fibrosis. Pediatrics. 48: 695 (1971).

36. Johanson, P. G., Anderson, C. M., and Hadorn, B.: Hypothesis. Cystic fibrosis of the pancreas. A generalized disturbance of water and electrolyte movement in exocrine tissues. Lancet, 1: 455 (1968).

37. Kraus, I. Antonowicz, I., Shah, H., Lazarus, $H$, and Schwachman, H. Metachromasia and assay for lysosomal enzymes in skin fibroblasts cultured from patients with cystic fibrosis and controls. Pediatrics, 47: 1010 (1971).

38. Louisot, P., and Leurat, C.: A new pathogenic hypothesis for cystic fibrosis: hyperactivity of glycosyl transferases at microsomic level. Clin. Chim. Acta, 48: 373 (1973).

39. Lowry, O. H., Rosenbrough, N. J., Farr, A. L., and Randall, R. J.: Protein measurement with the Folin phenol reagent. J. Biol. Chem., 143: 265 (1951)

40. Lustig, B., and Langer, A.: Biochem. Z., 242: 320 (1931).

41. Mangos, J. A., and McSherry, N. R.: Studies on the mechanism of inhibition of sodium transport in cystic fibrosis of the pancreas. Pediatr. Res. 2: 378 (1968).

42. Martin, F., Vuez, J. L., Berard, A., Andre, C., and Lambert, R.: A study of the mechanism of inhibition of peptic proteolysis by a sulphated polysaccharide. Digestion, $l: 165$ (1968).

43. Matalon, R., and Dorfman, A.: Acid mucopolysaccharides in cultured human fibroblasts. Lancet, 2: 838 (1969).

44. McCombs,M. L.: Research in cystic fibrosis: a review. Tex. Rep. Biol. Med., 31: 615 (1973).

45. McManus, S. P., and Masterson, J.: Cytoplasmic metachromasia in cultured skin fibroblasts from parents of children with cystic fibrosis. Ir. J. Med. Sci., 142: 227 (1974).

46. Molnar, J.: A proposed pathway of plasma glycoprotein biosynthesis. Mol. Cell Biochem. 6: 3 (1975).

47. Novak, R. A., and Abell, C. W.: L-Fucose metabolism in cystic fibrosis fibroblasts Tex. Rep. Biol. Med., 34(1): 199 (1976).

48. Padday, J. F.: Metachromasy of dyes in solution. In: E. A. Balazs Chemistry and Molecular Biology of the Intracellular Matrix. Vol. 2 p. 1007-1031 (Academic Press, New York, 1970).

49. Pearson, R. D., and Lubin, A. H.: A simple method for estimating a "heparin binding capacity" of human serum. Health Lab. Sci 15(I): 32 (1978).

50. Polley, M. J., and Bearn, A. G.: Cystic fibrosis: current concepts. J. Med. Genet, 11: 249 (1974).

51. Rao, G. J. S., Spells, G., and Nadler, H. L.: Enhanced UDP-galactose: glycoprotein galactosyltransferase activity in cultivated skin fibroblasts from patients with cystic fibrosis and its possible relationship to the pathogenesis of the of the disease. Pediatr. Res., 11: 981 (1977).

52. Rimington, C.: Biochem. J. 34: 931 (1940).

53. Shapira, E., Rao, G. J. S., Wessel, H. U., and Nadler, H. L.: Absence of an $\alpha-2-$ macroglobulin-protease complex in cystic fibrosis. Pediatr. Res., 10: 812 (1976).

54. Slack, J., Nair, S., Traisman, H., Becker, G., Hahler, S., and Yi-Yung, D.: Lipoprotein lipase in cystic fibrosis of the pancreas. J. Lab. Clin. Med., 59: 302 (1962).

55. Spiro, R. G.: Glycoproteins: their biochemistry, biology and role in human disease. N. Engl. J. Med., 281: 991, (1969).

56. Spock, A., Heick, H. M. C., Cress, H., and Logan, W. S.: Abnormal serum factor in patients with cystic fibrosis of the pancreas. Pediatr. Res., $l: 173$ (1967).

57. Sturgess, J. M., Minaker, E., Mitranic, M. M., and Moscarrello, M. A.: The incorporation of $\mathrm{L}$-fucose into glycoproteins in the golgi apparatus of rat liver and in serum. Biochim. Biophys. Acta, 320: 123 (1973).

58. Weimer, H. R., and Moshin, H. R.: Am. Rev. Tuberculosis, 68: 594 (1952)

59. Wiesmann, and Neufeld, E. F.: Metabolism of sulfated mucopolysaccharide in cultured fibroblasts from cystic fibrosis patients. J. Pediatr. 77(4): 685 (1970).

60. Wilson, G. B., and Fudenberg, H. H.: Studies on cystic fibrosis using isoelectric 
focusing. II. Demonstration of deficient proteolytic cleavage of $\alpha_{-2}$-macroglobulin in cystic fibrosis plasma. Pediatr. Res. 10: 87 (1976)

61. Wilson, G. B., Jahn, T. L., and Fonseca, J. R.: Demonstration of serum protein differences in cystic fibrosis by isoelectric focusing in thin layer polyacrylamide gels. Clin. Chim. Acta, 49: 79

62. Winzler, R. J.: Determination of serum glycoproteins. Methods Biochem. Anal., 2: 279 (1955).

63. Winzler, R. J.: Glycoproteins and glycosaminoglycans in plasma and in some other body fluids. In: E. A. Balazs and R. W. Jeanloz, The Amino Sugars. Vol. IIa. p. 337-352 (Academic Press, New York, 1965).

64. Young, M. D., Phillips, G. O., and Balazs, E. A.: Polyanions and their complexes. I. Thermodynamic studies of heparin azure A complexes in solution. Biochem. Biophys. Acta, 141: 374 (1967).

65. This project was reviewed and approved by the Human Subjects Research Committee of the Children's Hospital Research Foundation, Inc., Columbus, Ohio. Informed consent was obtained from human subjects according to

Copyright (C) 1979 International Pediatric Research Foundation, Inc $0031-3998 / 79 / 1307-0834 \$ 02.00 / 0$ guidelines established by the National Institutes of Health, U.S.A.

66. The authors thank Dr. Gordon Young, Director of the Children's Hospital Cystic Fibrosis Center for his cooperation and interest in our research efforts. We extend our thanks also to Miss Dottie Getreu of his office for her assistance in scheduling of patients who participated in this project. Our thanks are given also to Albert L. Caffo, Ph.D., for his technical advice, to Mrs. Denise Ruth for her technical assistance, to Mrs. Bernice J. Lubin, Ph.D. for her editorial efforts, and to Mrs. Amy Ward, Mrs. Jackie Johnson, and Mrs. Pamela Bishop for their secreterial assistance in preparation of this manuscript.

67. This research was supported by grant $81-779$ from the Children's Hospital Research Foundation, Inc., Columbus, Ohio (USA).

68. Requests for reprints should be addressed to: A. Harold Lubin, $M$. D., The Children's Hospital, Department of Pediatrics, The Nutrition Division, 700 Children's Drive, Columbus, Ohio 43205 (USA)

69. Received for publication January 11, 1978.

70. Accepted for publication July 19, 1978. 